\title{
Performance and intestinal viscosity in broilers fed diets containing dehulled or naked oats and enzymes
}

\author{
B. Szymczyk ${ }^{1}$, P. Hanczakowski and W. Szczurek \\ National Research Institute of Animal Production, \\ Department of Animal Nutrition and Feed Sciences \\ 32-083 Balice, Poland
}

\begin{abstract}
Changes in the viscosity of intestinal contents and growth performance of broiler chickens fed oat-based diets, as influenced by oat cultivar (dehulled or naked oats cv. Akt or Polar) and dietary level ( 150 or 300 and 250 or $500 \mathrm{~g} / \mathrm{kg}$, in starter and grower diets, respectively) and enzyme supplementation were investigated. The relative intestinal viscosity was determined at 21 and 42 days of age. The dietary level of oats, their cultivars and enzyme supplementation of diets had a significant influence on body weight gains and feed conversion in broiler chickens. The enzyme supplement significantly $(\mathrm{P} \leq 0.01)$ decreased intestinal viscosity and improved performance parameters in chickens.
\end{abstract}

KEY WORDS: naked oats, chicken performance, enzymes, digesta viscosity

\section{INTRODUCTION}

Naked oats (Avena nuda) are a valuable feed grain for poultry because of their beneficial nutritional properties (Hong et al., 2002; Kamińska, 2003). The absence of the indigestible husk can be predicted to give an increased metabolizable energy (ME) content. Further advantages of naked oats include a relatively high protein content, a high concentration of essential amino acids and polyunsaturated oils, and significant antioxidant activity (Kosieradzka and Fabijańska, 2001; Svihus and Gullord, 2002). However, the beta-glucans present at a level of 5-6\% in naked oats increase the viscosity of the intestinal contents and pose problems of nutrient availability and growth inhibition, especially in young chickens. The use of feed enzymes, including beta-glucanase, in oat-based diets has, in some experiments, improved broiler growth and feed efficiency

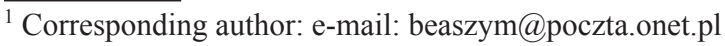


(Hetland and Svihus, 2001; Svihus and Gullord, 2002; Osek et al., 2003). The objective of this study was to determine the effect of enzyme supplements on performance and intestinal content viscosity in broiler chickens fed oat-based diets.

\section{MATERIAL AND METHODS}

A total of 520 one-day-old Cobb broiler chickens were randomly allocated to thirteen dietary treatments (four replications of ten birds each) and kept in battery cages. They were given a starter diet $(22.2 \% \mathrm{CP}$ and $12.5 \mathrm{MJ} \mathrm{ME} / \mathrm{kg})$ from 7 to 21 days and a grower diet $(19.7 \% \mathrm{CP}$ and $12.9 \mathrm{MJ} \mathrm{ME} / \mathrm{kg})$ from 22 to 42 days of life. The control diet was based on soyabean, maize and wheat, in experimental diets $150 / 300$ or $250 / 500 \mathrm{~g} / \mathrm{kg}$ (in starter and grower, respectively) of cereals was substituted by dehulled oat or naked oat cv. Akt or Polar. Diets were unsupplemented or supplemented with an enzyme preparation $(1 \mathrm{~g} / \mathrm{kg})$ which contained: $15 \mathrm{U}$ amylase, $14 \mathrm{U}$ protease, $400 \mathrm{U}$ beta-glucanase, $400 \mathrm{U}$ xylanase and $600 \mathrm{U}$ cellulase per gram. Chickens were weighed individually but feed intake was measured in each replication. At 21 and 42 days of age, four birds from each replication were killed and the ileum contents were removed, centrifuged and the relative viscosity of the intestinal contents (RIV) was determined using a capillary viscometer. The experimental results were analysed using three-way ANOVA generated by the STATISTICA v. 5.1 package. Duncan's multiple range test was used to determine the significance of differences between means.

\section{RESULTS AND DISCUSSION}

Overall, the RIV of chickens fed experimental diets was higher than in controls. However, the performance indices obtained in chickens receiving enzymes were similar or significantly better than those in control birds. The dietary level of naked oats, cultivars and enzyme supplementation of diets significantly influenced body weight gains (BWG) and the feed conversion ratio (FCR) in broiler chickens (Table 1). In the case of the higher level of oats, enzyme efficiency was higher ( $\mathrm{L}$ $\times$ E). The higher dietary level of both dehulled and naked oats $\mathrm{cv}$. Akt resulted in better FCR during days 1-21 of life, but had a negative effect on this parameter obtained for 1-42 days of feeding $(\mathrm{O} \times \mathrm{L})$. Kamińska (2003) found no significant changes of BWG and FCR in broilers receiving grower diets with $35 \%$ of naked oats, whereas Kosieradzka and Fabijańska (2001) showed a decrease of BWG of chickens receiving oats as the only cereal ingredient in the diet. Enzyme supplementation of diets containing cv. Akt oats resulted in the highest BWG $(\mathrm{O} \times \mathrm{E})$. The enzymatic supplement decreased $(\mathrm{P}<0.01)$ the viscosity of chicken digesta. The influence of enzymes was most effective in the case of birds receiving 
diets with dehulled oats $(\mathrm{O} \times \mathrm{E})$. Generally, chickens reacted to reduced RIV by significantly increasing BWG. There was also an enzyme-related improvement in feed conversion $(\mathrm{P}<0.01)$. Similar results were obtained in the studies of Svihus and Gullord (2002) and Lazaro et al. (2004).

Table 1. Experimental results in days 1-21 and 21-42 of life

\begin{tabular}{|c|c|c|c|c|c|c|c|c|}
\hline \multicolumn{3}{|l|}{ Dietary } & \multicolumn{2}{|c|}{$\begin{array}{c}\text { Body weight gain } \\
\mathrm{g}\end{array}$} & \multicolumn{2}{|c|}{$\begin{array}{c}\text { Feed conversion } \\
\text { ratio }\end{array}$} & \multicolumn{2}{|c|}{$\begin{array}{l}\text { Viscosity of the } \\
\text { intestinal content cP•s }\end{array}$} \\
\hline Oat & Oat level & Enzyme & $1-21$ & $1-42$ & $1-21$ & $1-42$ & 21 & 42 \\
\hline Control & - & - & 597 & 2039 & 1.54 & 1.91 & 1.36 & 1.70 \\
\hline Dehulled & $150 / 300$ & - & $575^{x}$ & 2035 & 1.59 & 1.88 & $1.81^{\mathrm{x}}$ & $2.21^{\mathrm{x}}$ \\
\hline Akt & $150 / 300$ & - & 587 & 2052 & 1.60 & 1.94 & $1.87^{\mathrm{x}}$ & $1.80^{\mathrm{x}}$ \\
\hline Polar & $150 / 300$ & - & 593 & 2059 & $1.64^{\mathrm{x}}$ & $1.97^{x}$ & $1.89^{\mathrm{x}}$ & $1.88^{\mathrm{x}}$ \\
\hline Dehulled & $250 / 500$ & - & $582^{x}$ & $2010^{x}$ & $1.63^{\mathrm{x}}$ & 1.94 & $2.18^{x}$ & $2.26^{\mathrm{x}}$ \\
\hline Akt & $250 / 500$ & - & $580^{x}$ & $2010^{x}$ & 1.61 & $1.96^{x}$ & $2.08^{x}$ & $1.89^{\mathrm{x}}$ \\
\hline Polar & $250 / 500$ & - & 591 & 2032 & $1.63^{x}$ & 1.95 & $2.33^{x}$ & $1.99^{x}$ \\
\hline Dehulled & $150 / 300$ & + & 599 & $2046^{x}$ & 1.55 & $1.82^{\mathrm{x}}$ & 1.39 & $1.84^{\mathrm{x}}$ \\
\hline Akt & $150 / 300$ & + & $621^{x}$ & $2071^{x}$ & 1.55 & $1.83^{x}$ & 1.43 & $1.64^{\mathrm{x}}$ \\
\hline Polar & $150 / 300$ & + & 601 & 2053 & 1.60 & 1.86 & $1.48^{x}$ & $1.78^{\mathrm{x}}$ \\
\hline Dehulled & $250 / 500$ & + & 597 & 2053 & 1.57 & 1.86 & $1.70^{\mathrm{x}}$ & $1.85^{\mathrm{x}}$ \\
\hline Akt & $250 / 500$ & + & 597 & $2060^{x}$ & 1.58 & 1.89 & $1.69^{\mathrm{x}}$ & $1.79^{\mathrm{x}}$ \\
\hline \multirow[t]{2}{*}{ Polar } & $250 / 500$ & + & $615^{x}$ & $2092^{x}$ & 1.54 & $1.84^{\mathrm{x}}$ & $1.72^{\mathrm{x}}$ & $1.79^{\mathrm{x}}$ \\
\hline & & & \multicolumn{6}{|c|}{ Main effect means } \\
\hline \multicolumn{8}{|l|}{ Oat $(\mathrm{O})$} & $2.04^{\mathrm{A}}$ \\
\hline & Akt & & $596^{\mathrm{C}}$ & $2048^{\mathrm{C}}$ & 1.59 & $1.90^{\mathrm{A}}$ & $1.77^{\mathrm{B}}$ & $1.78^{\mathrm{C}}$ \\
\hline & Polar & & $600^{\mathrm{A}}$ & $2059^{\mathrm{A}}$ & 1.60 & $1.91^{\mathrm{A}}$ & $1.85^{\mathrm{A}}$ & $1.84^{\mathrm{B}}$ \\
\hline \multicolumn{9}{|c|}{ Oat level $(\mathrm{L})^{1}$} \\
\hline & low & & 594 & $2052^{\mathrm{A}}$ & 1.59 & $1.88^{\mathrm{A}}$ & $1.64^{\mathrm{A}}$ & $1.84^{\mathrm{A}}$ \\
\hline \multicolumn{9}{|c|}{ Enzyme (E) } \\
\hline & - & & $583^{\mathrm{A}}$ & $2033^{A}$ & $1.62^{\mathrm{A}}$ & $.94^{\mathrm{A}}$ & $2.03^{\mathrm{A}}$ & $1.99^{\mathrm{A}}$ \\
\hline & + & & $604^{\mathrm{B}}$ & $062^{\mathrm{B}}$ & $1.57^{\mathrm{B}}$ & $85^{\mathrm{B}}$ & $1.57^{\mathrm{B}}$ & $1.78^{\mathrm{B}}$ \\
\hline \multirow{2}{*}{\multicolumn{3}{|c|}{ Pooled SEM }} & 2.17 & 3.32 & 0.05 & 0.07 & 0.03 & 0.03 \\
\hline & & & \multicolumn{6}{|c|}{ Significant interactions $(P \leq 0.01)$} \\
\hline $\mathrm{O} \times \mathrm{L}$ & & & $*$ & $*$ & $*$ & $*$ & $*$ & NS \\
\hline $\mathrm{O} \times \mathrm{E}$ & & & NS & * & NS & $*$ & NS & $*$ \\
\hline $\mathrm{L} \times \mathrm{E}$ & & & NS & $*$ & NS & NS & $*$ & NS \\
\hline $\mathrm{O} \times \mathrm{L} \times \mathrm{E}$ & & & $*$ & $*$ & NS & NS & $*$ & NS \\
\hline
\end{tabular}

${ }^{1}$ low - 150/300; high - 250/500 g/kg in starter/grower diets

$A, B, C$ - within treatment values in columns with different letters differ significantly $(\mathrm{P}<0.01)$

$\mathrm{X}$ - means in columns differ significantly from control $(\mathrm{P}<0.01)$ 


\section{CONCLUSIONS}

The results of the study showed that, under the condition that enzyme supplements are used, naked oats can be included in diets for broiler chickens with no negative effects on growth performance. It is probable that the addition of enzymes diminished the adverse effect of viscous non-starch polysaccharides originating from oats, and this was reflected in reduced intestinal viscosity, better growth and feed utilization.

\section{REFERENCES}

Hetland H., Svihus B., 2001. Effect of oat hulls on performance, gut capacity and feed passage time in broiler chickens. Brit. Poultry Sci. 42, 354-361

Hong D., Burrows H., Adeola O., 2002. Addition of enzyme to starter and grower diets for ducks. Poultry Sci. 81, 1842-1849

Kamińska B., 2003. The effect of various grains in grower diet on broiler performance and dietetic value of carcass. Ann. Anim. Sci., Suppl. 2, 185-188

Kosieradzka I., Fabijańska M., 2001. Effect of beta-glucans of naked oats on its energetic value for broiler chicks. Ann. Warsaw Agr. Univ., Anim. Sci. (special number), 238-246

Lazaro R., Latorre M.A., Medel P., Gracia M., Mateos G.G., 2004. Feeding regime and enzyme supplementation to rye-based diets for broilers. Poultry Sci. 83, 152-160

Osek M., Janocha A., Klocek B., Wasiłowski Z., Milczarek A., 2003. The influence of different content of naked oat in plant feed on performance and post-slaughter value of broiler chicken. Ann. Anim. Sci., Suppl. 2, 205-208

Svihus B., Gullord M., 2002. Effect of chemical content and physical characteristics on nutritional value of wheat, barley and oats for poultry. Anim. Feed Sci. Tech. 102, 71-92

\section{STRESZCZENIE}

\section{Wskaźniki produkcyjne oraz lepkość treści jelitowej u kurcząt brojlerów żywionych dietami zawierającymi owies obłuszczony lub nagoziarnisty z dodatkiem enzymów}

W układzie złożonym badano lepkość treści jelitowej i wyniki odchowu kurcząt brojlerów żywionych dietami zawierającymi różne ilości owsa obłuszczonego lub nagoziarnistego (odmiany Akt lub Polar), stosowanymi z dodatkiem lub bez dodatku wieloskładnikowego preparatu enzymatycznego. Diety typu starter zawierały 150 lub 300, a diety typu grower 250 lub $500 \mathrm{~g} / \mathrm{kg}$ owsa. Względną lepkość treści jelitowej oznaczano u kurcząt w 21 i 42 dniu życia. Udział owsa w diecie, odmiana jego oraz dodatek enzymu do mieszanek miały istotny wpływ na przyrost masy ciała oraz wykorzystanie paszy w obydwóch okresach odchowu. Dodatek enzymu obniżył lepkość treści jelitowej $(\mathrm{P}<0,01)$, zwiększając przyrosty masy ciała i poprawiając wykorzystanie paszy $(\mathrm{P}<0,01)$. 